トランポリンに於ける啳方宙返り抱型の 分析的研究

\section{I. 研究目的}

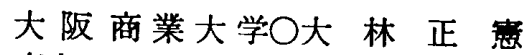
東京女子体育大学 長谷川 蚂

Trampoline に於ける後方宙返り抱型は，基礎種目を マスターしたトランポリナーが次に進さ種目として前方 宙返り抱型と共に代表的な種目である。そこで，この種 目に熟達している者と，そうでない者とを比較・分析し てみてトランポリンに於ける後方宙返り抱型の理想像と それに近ずく為にはどらすればよいかを合せて究明しよ らとするものである。

\section{II. 研究の対象と方法}

トランポリンに於ける後方宙返り抱型の熟䊓者と未熟 練者を男子各々 1 名ずつ選出し，両名に同一のトランポ リンで後方宙返り抱型を行わせ，これを側面より撮影機 を固定して高速撮影し，その結果を分析した。 (1) 対 象. 熟綀者 1 名（経呀年数約 4 年），末熟綀者 1 名（程 験年数約 1 年). (2) 撮影方法. 16 ミリカメラでレンズ の高さ $1.5 \mathrm{~m}$ に固定し，レンズとトランポリンの中央と の距離を $20 \mathrm{~m}$ にして撮影した。（3）フイルムの時間決 定, 落体浿定を撮影し，その時のフイルムのクリック数 で時間を决定した。この落体測定の結果，クリツク数は 1 秒間に 22 数えられた。

\section{II. 結果と教家}

トランボリンに於ける後方宙返り抱型の足がベッドか ら離れて再びペッドに着く迄の身体が空間に浮いている 時間を便宜上，側面から見た空間を座標平面と考え，胴 体の移動を〔第 1 図〕の如く区分した．そして，その結 果を熟練者と末熟練者に分けてまとめたのが〔第 1 表〕 である、これに依ると最も著しい差がみらるのは，第 1 ，第 2 象限と第 3 ，第 4 象限の 2 つの面に分けた場合に 要した時間の比率である.これは，熟綀者がゆつくりし た回転で上昇し，高い位䀦で素早く回転し，再びゆつく りした回転で降りているのに対し，末熟練者は直ぐに上 体を倒し，回転することのみに力を向けて上界力を弱め ている.この為に高さがとれず，かえつて回転力す弱ま つている事を示している。

次に〔第 1 図〕と同じ様に，頭の移動について区分し たので〔第2図〕で，それをまとめたものが〔第2表〕 である．これでみると両者共へッド・アップが見られる が，この場合も未熟練者の方がよりはげしいことがわか る.ヘッド・アップする事に依つて頸矨反射が起り，自 然とタックが甘くなり，回転がのろくなるのでへッド・ アップは良くない, 向, 熟練者, 未熟練者共第 2 象限之 第 1 象限が胴体の場合よりも短かくなつているのは正向 反射が働いている為で，この場合もやはり熱綀者の方が より発達している様である。

IV. ¿とめ

熟練者と末热綀者を比较分析してみることに依つて明 らかになつたトランポリンに於ける後方宙返り抱型の理 想像は次の通りである。
胴体之頭の移動については，第 3 象限之第 4 象限に要 する時間を等しくなる様に，しかも出来るだけこの間の 時間の比率を長く保つことである. 又, 第 2 象限，第 1 象限に要する時間の比率は出来るだけ短かくし, そして この場合も第 2 象限に要する時間と第 1 象限に要する時 間も等しく保つことである.

何, 身体全体の移動については，上昇時には上昇力を 強く，より高さをとる為に垂直に近い姿勢で上昇し，頂 点に近い所で素早く回転し，出来るだけ高い位置で回転 を終え，次の動作の為に余裕をすつて降りることで, 踏 切つた地点と同じ場所に降りることが理想的である. そ の為には出来るたけ高く, 真上に振り上げ, ヘッド・ア ップをしないでむしろ前を見ながらかがう，睩のひきつ けは初めの内はゆつくりと, 頂点に近い所で素早くひき つけるその膝を早くひさつけると同時に頭を強く後に引 き, 回転を早め, 着地点を早く確認し、次の動作に備え る. それ故，手は真上に振り上げたままの姿勢で膝が上 つて来るのを待ち出来るだけ早く㰚すことが大切であ る.

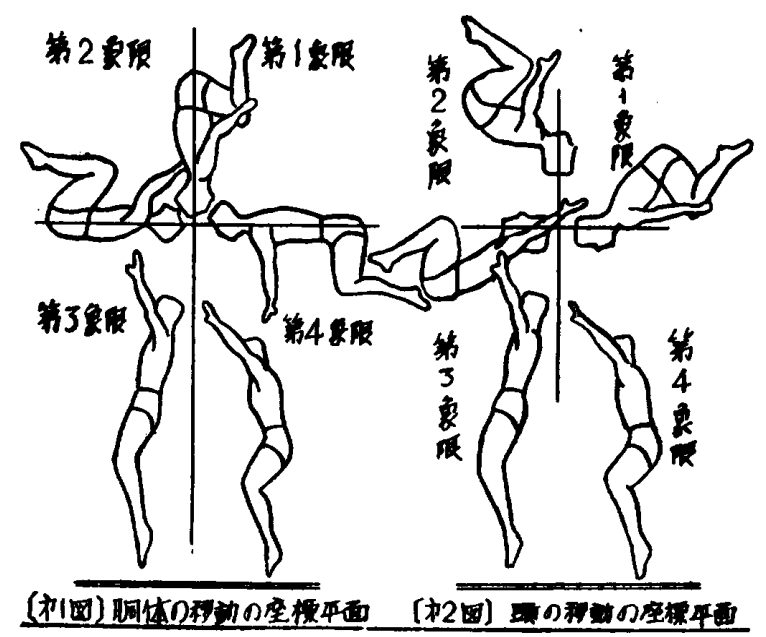

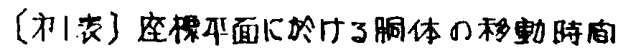

\begin{tabular}{|c|c|c|c|c|c|c|}
\hline & 庐了象眼 & わ2象㖘 & 独象层 & 才4免限 & 言† & 高さ \\
\hline 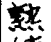 & 0.50 利 & 027 杪 & 0.27 & 0.45 杪 & \multirow[b]{2}{*}{ 149秒 } & \multirow[b]{2}{*}{$2.68 \mathrm{~m}$} \\
\hline 缕 & $34 \%$ & $18 \%$ & $18 \%$ & $30 \%$ & & \\
\hline 氺 & 036 秘 & 0.27 秘 & 0.36 枌 & 027 秒 & \multirow[b]{2}{*}{ 1.26秒 } & \multirow[b]{2}{*}{$1.94 \mathrm{~m}$} \\
\hline 蛲 & $29 \%$ & $21 \%$ & $29 \%$ & $21 \%$ & & \\
\hline
\end{tabular}

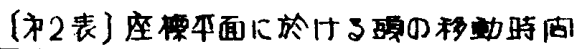

\begin{tabular}{|c|c|c|c|c|c|}
\hline & 市了象眼 & 加国 & 中象展 & 力4 数展 & 部 \\
\hline 施 & 0.41 私 & 0.18 利 & 0.27 秒 & 0.63 & \\
\hline 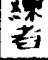 & $27 \%$ & $12 \%$ & $18 \%$ & $43 \%$ & 1.49秒 \\
\hline 委 & 0.27 私 & 0.225 秒 & 0.35171 & $0.45 \#$ & \\
\hline 策 & $21 \%$ & $18 \%$ & $25 \%$ & $36 \%$ & 1.26 秒 \\
\hline
\end{tabular}

